\title{
Dipnoan from the Upper Triassic of East Greenland and remarks about palaeobiogeography of Ptychoceratodus
}

\author{
Wojciech Pawlak, Mateusz Tałanda, Tomasz Sulej, and Grzegorz Niedźwiedzki \\ Acta Palaeontologica Polonica 65 (3), 2020: 561-574 doi:https://doi.org/10.4202/app.00679.2019
}

Here we present a description of the dipnoan remains collected from the middle to upper

Norian (Upper Triassic) of Jameson Land, East Greenland. The specimens consist of isolated tooth plates and skull bones of Ptychoceratodus, the most complete Late Triassic dipnoan material from Greenland. This genus is reported for the first time from the Upper Triassic of Greenland. The studied material belongs to Ptychoceratodus rectangulus previously known from the middle-upper Norian of Germany. It fills the biogeographical gap between the records of the Germanic and the Jameson Land basins. A reconstruction of the skull roof is provided, based on isolated bones collected from the same bone-bed. Their good preservation enables recognition of the sensory line pits, arranged similarly as in the extant Protopterus, suggesting a comparable mode of life. This finding has implications for our understanding of the disparity in Ptychoceratodus dipnoans, as well as the morphology between closely related dipnoans of the Late Triassic ecosystems.

Key words: Dipnoi, Ptychoceratodus, Triassic, Norian, Greenland, Carlsberg Fjord Beds.

Wojciech Pawlak [wojciech.pawlak@student.uw.edu.pl] and Mateusz Tałanda [m.talanda@biol.uw.edu.pl], Department of Palaeobiology and Evolution, Faculty of Biology, Biological and Chemical Research Centre, University of Warsaw, Żwirki i Wigury 101, 02-089 Warsaw, Poland. Tomasz Sulej [sulej@twarda.pan.pl ], Institute of Paleobiology, Polish Academy of Sciences, Twarda 51/55, 00-818 Warsaw, Poland. Grzegorz Niedźwiedzki [grzegorz.niedzwiedzki@ebc.uu.s], Department of Organismal Biology, Evolutionary Biology Center, Uppsala University, Norbyvägen 18A, 75236 Uppsala, Sweden.

This is an open-access article distributed under the terms of the Creative Commons Attribution License (for details please see creativecommons.org), which permits unrestricted use, 
distribution, and reproduction in any medium, provided the original author and source are credited.

For Full text $(1,032.2 \mathrm{kB})$ 